\title{
Persistence and Disappearance of Hyaloid Artery in Newborn Cynomolgus Monkeys
}

\author{
Michihiro T. SUZUKI, Hayato NARITA, Fumiaki CHO* \\ and Masanobu FUKUI** \\ The Corporation for Production of Laboratory Primates, and *Tsukuba Primate \\ Center for Medical Science, The National Institute of Health, \\ Hachiman dai, Yatabe-machi, Tsukuba-gun, Ibaraki-ken 305, \\ Japan and **Institute of Basic Medical Sciences, The \\ University of Tsukuba, Tennodai, Sakura- \\ mura, Niihari-gun, Ibaraki-ken 305.
}

(Received 2 September 1983/Accepted 7 December)

\begin{abstract}
Apparently healthy 45 newborn cynomolgus monkeys (Macaca fascicularis) were examined for the persistence and disappearance of the hyaloid artery by using an opthalmoscope. On the day of birth, the hyaloid artery was observed in all the newborn animals. Between 21 and 45 days of age, the hyaloid artery faded without exception. The persistence of the hyaloid artery in the newborns and its disappearance during an early period of life can be regarded as a normal phenomenon in the developmental process of infant cynomolgus monkeys.
\end{abstract}

\section{カニクイザル新生仔における硝子体動脈遺残と その消退時期}

\author{
鈴木通弘・成田勇人・長文昭* \\ 福井正信 ${ }^{* *}$ \\ 社団法人予防衛生協会 \\ *国立予研筑波医学実験用霊長類センター \\ **筑波大学基礎医学系
}

硄子体動脈の消退時期は動物種により異なり, 胎生期 に消退が恋められる種と生後に消退をみせる種 [5-6]の それぞれが報告されている。マカカ属中, アカゲザルで は, 検眼鏡検査において, 出生後な掞硝子体動脈が認め られ， $2 \sim 3$ 週路時に消退することが報告されている [2-3]。本論文に打いては検眼鏡検査による 新生仔力二 クイザルの硝子体動脈遺残とその消退時期について報告
する。

動物は当センターで繁殖・育成されたカニクイザルを 対象とした。まず，出生時の硝子体動脈遺残の有無に関 し45頭につき観察し，うち17頭はその消退時期を確認の ため, 日畧在追って観察を続行した。観察は出生日より 週 2 回, 3〜4 日間隔で行い, 硝子体動脈を確恋し得な い日が 2 回連続するまで実施した。観察にあたっては, 
対象動物の両眼にトロピカミト・塩酸フェニレフリン (ミドリン $\mathrm{P}$, 参天製薬) を滴下し散瞳後, 携带用眼底 カメラ（R C-II 型，興和）により撮影を抗こなった。 フィルムは国産カラーフィルム（フジクローム100）在 用いた。

0 日齢に抢いて, 観察カニクイザル45頭の全例に, 硝 子体動脈遺残像が確認された。すなわち, 血管は眼球後 極部円板中央から硝子体在通過し, 水晶体に到達してい た (Fig. 1，2)。Fig. 3 に硝子体動脈遺残像の消退時 期を示した。この遺残像は21〜 45日齢, 平均27日齢に消 失した。

先天異常のひとつとされる硝子体動脈遺残はイヌ $[7]$ その他の家畜 [8]やアカゲザル［9]に掠いて報告されて

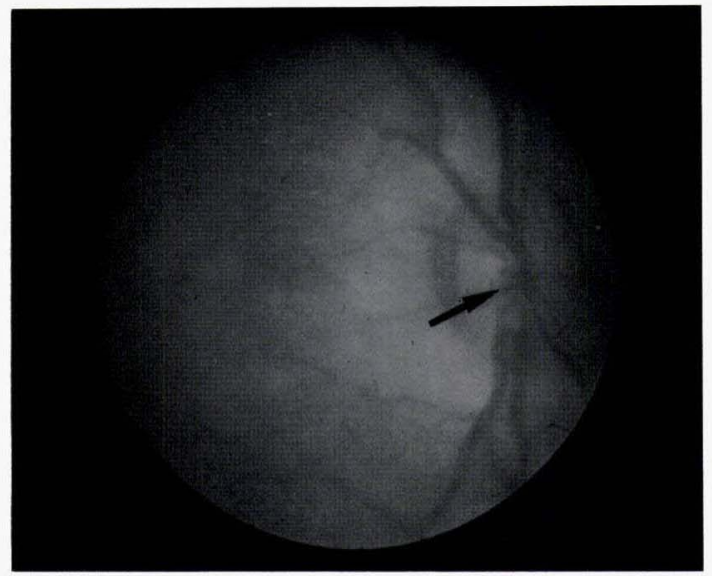

Fig. 1. The ocular fundus of the 0 day old cynomolgus monkey. Showing the end of hyaloid artery (arrow).

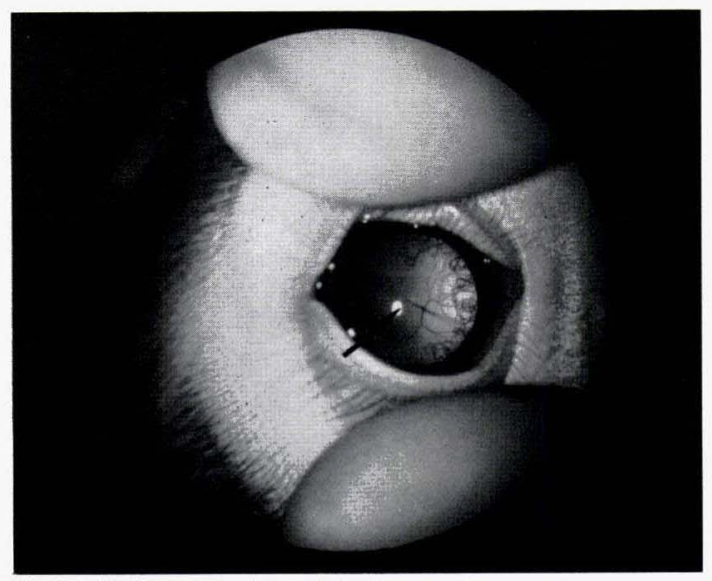

Fig. 2. Persistent hyaloid artery (arrow) of the 0 day old cynomolgus monkey.

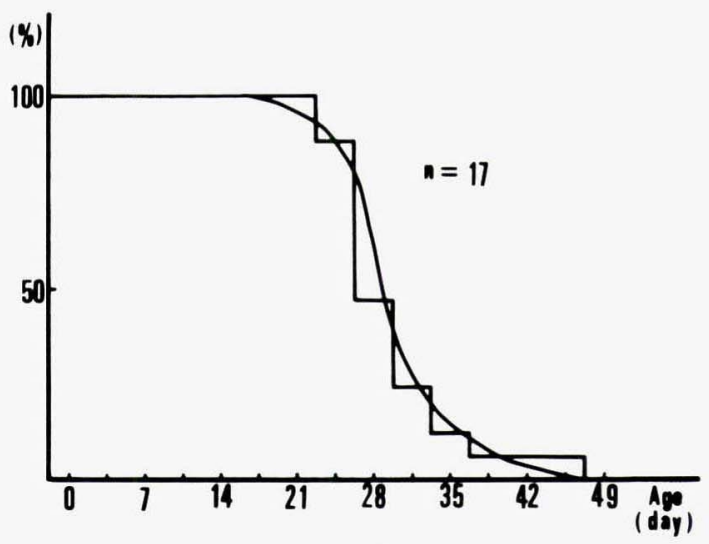

Fig. 3. Fading of the hyaloid artery in the infant stage of cynomolgus monkeys.

いるが，一般に，胎生期もしくは出生後の早期に消退す ることが知られている[5-6]。

サル類に打ける硝子体動脈遺残について, Hamming ら [1]は16頭の胎齡85日齢から生後 3 歳齢のベニガオザ ル及びカニクイザルの眼球組織を観察し, 出生後 $3 \sim 4$ 週澮に扣いて消退すると報告している。一方，検眼鏡検 查では，Ordy [4]は1日齢のアカゲザル4頭に执いて， 硝子体動脈遺残は認められないと報告している。しかし， Johnson [2-3]は，健康な 1 日齢のアカゲザル 15 頭を 観察し，全例に硝子体動脈遺残圭認め，さらに，その消 退時期は $2 \sim 3$ 週路時であると報告している。著者らの 今回のカニクイザルの観察でも0 日齢時に硝子体動脈遗 残を 全例確認し，21〜45 日齢時に抢ける消退を記録し た。ここで, 消退時期について, 著者らのカニクイザル と Johnson らのアカゲザルとの間に若干の差がみられ る。この差については, アカゲザル, カニクイザルの双 方で今後例数をふやし比較検討守る必要があろう。

アカゲザルと同様，カニクイザルの出生時に認められ た本現象は，先天異常もしくはその他の原因に起因する ものではなく，正常な現象と結論される。

\section{要 約}

0 日齢のカニクイザル45頭の眼観察において，例外な く硝子体動脈遺残像を認めた。本像は21～45日齢におい て全例消失した。したがって, 出生時の硝子体動脈遺残 はカニクイザルにおいては正常な現象と考えられた。

終りに臨み，終始御指導いただき，かつ，本論文を校 閲頂いた国立予研筑波医学実験用霊長類センター所長本 
庄重男博士に潹く感謝の意を表する。

\section{文献}

[1] Hamming, N. A., Apple, D. J., Gieser, D. K., and Vygantas, C. M. (1977). Invest. Ophthalmol. Visual Sci., 16, 408-415.

[2] Johnson, P. T., Tucek, P., and McGowan, M. A. (1977). Vet. Med. Small Anim. Clin., 72, 645-648.

[ 3 ] Johnson, P. T. (1979). J. med. Primatol., 8, 184186.

[4] Ordy, J. M., Massopust, L. C., Jr., and Wolin, L.
R. (1962). Exptl. Neurol. 5, 364-382.

[5] Quinn, A. J. (1981). Canine Practice, 8, 19-25.

[6] Riis, R. C. (1981). In Textbook of veterinary ophthalmology, pp. 569-605. Kirk N. Gelatt (edit), Lea \& Febiger, Philadelphia.

[7] Rubin, I. F. (1974). In Atlas of veterinary ophthalmoscopy, pp. 65-244. Lea \& Febiger, Philadelphia.

[8] Rubin, I. F. (1974). In Atlas of veterinary ophthalmoscopy, pp. 327-366. Lea \& Febiger, Philadelphia.

[9] Rubin, I. F. (1974). In Atlas of veterinary ophthalmoscopy, pp. 399-423. Lea \& Febiger, Philadelphia. 